\title{
Short Run Learning Model for Physical Education Students
}

\author{
Heru Sulistianta*, Ziko Fajar Ramadhan \\ Pendidikan Jasmani, Kesehatan dan Rekreasi \\ Universitas Lampung \\ Lampung, Indonesia \\ *heru.sulistianta@yahoo.com
}

\begin{abstract}
The objective to be achieved from this research and development is the Learning Model Development of run the short distance for the Student of Physical education, health, and recreation program of University of Lampung. Research and development was done to get information about the development and the application of the Development Model of learning-based short-haul Run Game on the Physical education, health, and recreation program students and to know the effectiveness of the resulting model. This research method used Research \& Development (R\&D) of Borg and Gall. The subjects in this study were students of the University of Lampung that consisted of 40 students. Stages in this study were: needs analysis, experts' evaluation (evaluation of early product), the free trial of small groups, and large group test (field testing). To test the effectiveness of the model, a test of short run learning was used to know the short run before and after administering the treatment model developed bouts of exercise. Initial tests were conducted to obtain the ability level of short run, thus preferential treatment can be given. After 7,266 learning model short run distances, the value of 6,095 was obtained. On the test of significance differences with SPSS 16, it obtained mean $=1,171$, showed the difference between the results of pre-test and the results of the test, the results of the post $t$-count $=4,083 \mathrm{df}=74$ and $p$-value $=$ 0.0100 .05 means that $<$ significance of difference between before and after the treatment of learning model short run distances was given. Therefore, learning games based short distance running for student in Lampung University is effective to improve short running skill.
\end{abstract}

Keywords: models, learning, short-haul run

\section{INTRODUCTION}

Of Athletics primarily ran the short distance to have special characteristics or styles that provide opportunities to individuals to perform to its full potential, so that one is required to have a good physical fitness [1]. Physical fitness is in the form of physical fitness that is primed to support the appearance of a person [2]. The physical preparation is an important thing in preparation of a team to achieve the optimal achievement. As has been mentioned earlier that physical fitness physical fitness form greatly affect a person's appearance. Through physical exercise, the less good condition will increase [3]. After doing physical exercises are programmed properly, the result of physical exercise can be seen from the increasing appearance of someone who is ultimately a positive impact towards appearance [4,5].

The result of the observation in the field there are few data on higher education especially in Physical education, health, and recreation program University of Lampung is still there or not there is a new model of learning is mainly short-haul run Athletics-based game that is based on the on the measurement that is accurate, valid, reliable, easy, efficient, effective, and enjoyable, it does not cover the possibility of a program implemented by the lecturer in question but has not been based on the principle of learning that is clearly referring to the study of a learning model that aims to positively impact of appearance after implementing a learning model [6]. There is a phenomenon of a monotonous learning from semester to semester next with the same learning material.

\section{THE STUDY OF THEORY}

In order to improve the quality of education so any effort to improve the quality of education needs to be done through research. Research is one of the steps used to solve a problem that there are scientifically. In order for this research can generate accurate information, research can be divided into some form of applied basic research, i.e., evaluation, development and urgent. Division of research based on function and its application in education and how long the results can be used namely research and development [7]. Research Development (Development Research) found the pattern, the sequence of growth, change and especially has the purpose to develop learning materials for schools. An example of the development of teaching materials is a textbook, props, learning modules and so on. Development research is research that is not being used to test the theory, but what is produced $[6,8]$.

In general terms the conceptual framework refers to a model that is used as a guideline or reference in conducting activities. In terms of the other models are also defined as goods or objects imitations of real objects. In terms of the model is used to show understanding as the first frame of thought process. While the basic model used for the generic model that shows the public and fundamental means to be the starting point for further model development in terms of more complicated and more in the sense of the new [9]. 
Skills and knowledge in research is needed to address the issues and challenges facing the present to be able to take a decision. Such as posed Emzir research or research (research) is an activity or a systematic process to solve the problem which is done by applying the scientific method [10].

Research and development of this learning model will be designed in the draft model serving development model forms the basic motion based games or games. So the draft models formulated later on could be the image of teachers in preparing learning materials athletics [11].

So the development of learning models are the result of research results-oriented product development. Research and development (Research and Development) according to Borg \& Gall is a process used to develop and validate product education [12]. Research on the development of a research approach that is linked on the design and development work as well as having the aim to design in the environment of learning and strive for the understanding of scientific fundamentals. Research development not to itemize and apply a comprehensive intervention but aimed to provide the motivation of learning by showcasing an interesting and creative learning $[5,13]$.

Thus the development of research can be concluded as research that produces a product that has been analysed in advance the level of effectiveness in learning or learning, and has been designed, evaluated and revision with the results of the development on the model. In this case that will be developed is the development Model drills run short distances at student Physical education, health, and recreation program University of Lampung [12,14]. Learning is the translation of the word "instruction" most people usually distinguish this learning with the word "teaching", but not infrequently also gives people the same sense for both those words. According to Sardiman the notion of learning are as follows: the words learning and teaching can be said not to be understanding. If the word teaching only exists in the context of teacher-pupil in formal classes, whereas the word learning not only exists in the context of teacher-pupil in formal classes, but also includes the teaching and learning activities that are not attended by physically [2].

Unlike the case of learning according to Sukmara, "Learning is an attempt the creation of conducive conditions in the sense of evoking an effective learning activities among students". With this conception needs to realize that the problem which determines in not learning methods or procedures used, not old or modern, progressive conventional learning or teaching. It may be important, but does not constitute a final consideration, because it is only concerned with the tools is not a destination [15]. Study of motion is the study of the process of involvement in acquiring and perfecting motion skills (motor skills). Because motion skills are very tied to the practice and experience of the individual concerned. Ma'mun, and S suggests, "in the learning process, there are three things that can be identified and need to get consideration, namely:" (a) the stage of cognitive-verbal, motor phases (b), (c) the stage of automation [14].

The concept model is complex. The Act that the complex can be translated as the use of integrative components contained in the deed that conveyed the message to faculty teaching. Therefore, in the world's good teacher teaching using a prototype of a theory or model. Called the model because it is only an outline or trees that require the development of a very circumstantial [12] Learning is not just passing on information or knowledge, but customize the learner to learn, because the primary purpose of learning is that learners learn. The success of teachers provide effective learning is characterized by the presence of learning on learners. The success of the learning process is affected by developments in science and public life that take place from time to time [16].

The learning process is the interaction between teachers with learners. The process not only through the giving of the information except through mutual communication between teachers and learners. Through this mutual communication, learners are given the opportunity to be actively involved in learning both mentally, intellectually, emotionally, and physically to seek and find knowledge, attitudes, and skills. That ability is expected to form his personality and can be applied in everyday life. While teachers provide guidance and customize the circumstances or environment that may encourage the learners to learn and can gain experience of learning with the goal of shaping his personality [6]

Understanding motion learning or learning of motor learning in general terms. Learning can be understood as a process of changing the entire behaviour in a person. Learning is a process in which there are many things that may happen to any self of an individual. To obtain objective understanding of learning especially learning, need to be clearly formulated the notion of learning [10,22]. In the sport of Athletics running sprints or run a short distance is run, which travels the distance between $50 \mathrm{~m}$ up to a distance of $400 \mathrm{~m}$, therefore the main needs to run a short distance is speed. Speed in short distance running is the result of a strong and rapid contraction of muscles is converted into smooth movements smoothly and efficiently and much needed for the runner to get high speed $[9,17]$. At the stage of learning by playing or games aimed to introduce the problem of motion (movement problems) run a short distance directly, and how to run a shorter distance right reviewed is anatomically correct attitude ran a short distance and increase the motivation of students towards learning, so that in the end can improve the physical fitness of students. Special purpose in playing the run a short distance is increased reaction moves, speed and acceleration of motion coordination as well as the students, students in the running. In some forms of play that can be given, i.e. the form of individuals, small groups or large groups [11].

\section{RESEARCH METHODOLOGY}

In general the purpose of this research is to produce shorthaul run learning model-based game against a college student Physical education, health, and recreation program University of Lampung. Specifically the aim of this research is:

- How is the development of a model of learning-based short-haul run game against the University of Lampung Physical education, health, and recreation program Students? 
- How is the test of the effectiveness of the development model of short-haul dash-based learning games to improve the effectiveness of the learning Physical education, health, and recreation program students against University of Lampung?

In this study, researchers are referring to the models of the development of Research and Development (R\&D) of Borg and Gall, research development education is a process used to develop and validate product education. The result of the research of the development of not only the development of an existing products but also to find the answers to the knowledge or practical problems [12]. The research is preliminary measures used to assess the State of the field with the goal of improved models are accepted or not by the subject. Preliminary research done by doing a study of literature, observation, field data collection, observation of the process of the exercise, the identification of the problems encountered in practice, and interview the teacher/trainer/extracurricular Constructor regarding the model developed researchers [17]. After conducting preliminary research, the next step is planning the development of the model. The draft was initially in the form of the creation of the learning model run short distancebased learning games in athletics. In the manufacture of this model developed, researchers create model later in the test Cobakan but previously consulted and tested by experts. In this role as the expert judgement and provide input on the model in the refinement of the models to the test in the Cobakan in the field $[12,18]$.

Field test or a large group was held at the University of Lampung, Penjaskes Prodi as a representative of a large group for 8 times. From the Group of field trial activities intended to know the effectiveness of changes made before, and it can be possible to use within the scope of that truth. To know the success of the implementation of the model developed, researchers in this section will describe the subject of the trial, the data type, and instruments used to test the feasibility and effectiveness of the model by including engineering testing the validity of the instrument (test statistics) as its data analysis [19]. In product development, subject tests used include: a trial for the Student groups there are two test groups namely: 20 people to test your small group and 60 students from Physical education, health, and recreation program University of Lampung for test group large.

\section{RESULTS AND DISCUSSION}

Of the development of the model of running shorter distance Learning on Student Physical education, health, and recreation program University of Lampung is intended in order to produce models of learning an effective short-haul Dash and more in price [20]. The data results of the needs analysis are presented in several ways, namely the interview Physical education, health, and recreation program Lampung University Student Lecturer University of Lampung and the dissemination of the questionnaire to students of Physical education, health, and recreation program University of Lampung. Data validation results will be presented by three athletic experts obtained through the questionnaire. Data from the results of the tests of the group that came from a member of the Student Physical education, health, and recreation program University of Lampung with how to fill out a detailed questionnaire to test instrument of small groups with 20 persons the subject of field trials, as much as 60 person subject, and test the effectiveness as many as 40 people are subject [21].

Run a short distance learning model is made on the basis of the problems discovered by investigators in field through the process of observation and interviews through a questionnaire given to researchers. Based on the results of observation and interview approaches, researchers will try to provide solutions to these problems by way of developing the learning model Run short distances [13], [22]. Based on data obtained through interviews and investigators question form to 60 Students Physical education, health, and recreation program University of Lampung and further processed and described. Outline of the research done to students of Physical education, health, and recreation program University of Lampung was implemented in January 2018[10]. Needs analysis in the form of the now. On the basis of the needs analysis can note that: (1) students of Physical education, health, and recreation program University of Lampung very interested to follow Learning activities ran the short distance (2) student of Physical education, health, and recreation program University of Lampung was bored with variation of learning Run short distances a monotonous (3) student of Physical education, health, and recreation program University of Lampung agree if developed Learning model Run short distances. for students of the University of Lampung (4) Lecturer Athletics requires Learning models Run short distances (5) Professors require references to media in the form of electronic or non-electronic books to support the learning process. After the researchers doing the collection and creation of draft models Learning Run short distances for students of the University of Lampung. The next step is done researchers tested experts. Testing experts conducted aiming to get the feasibility or the validity of the model produced by judgements directly from the athletics. Researchers bring 3 people are experts in the field of Athletics two profession as a lecturer of sports and an athletic trainer in an assessment of the feasibility of the model of Running shorter distance Learning for students of Physical education, health, and recreation program University of Lampung . After running a short distance Learning model for university students of Lampung has been evaluated by experts, models are at the evaluation phase 1 undertaken by experts as a reference for researchers in carrying out the next stage. After a small group of trial Run a short distance Learning model for university students of Lampung and revised by the athletics, then the next stage is to conduct tests of the large groups. Based on the results of the tests of the small group who have been evaluated by experts, the next researchers do initial product revisions and gained 19 run a short distance Learning model for university students Float that will be used on the large group trials $[10,12,23,24]$

The results of pre-and post-test Ran the short distance to the Students University of Lampung. Test pre-test done after the revision is done in small groups and large groups. Pre-test carried out prior to application of 19 Short Run Learning model for university students of Lampung. The test is done to find out the results before treatment is given. The average test results 40 Students Physical education, health, and recreation program University of Lampung was given treatment After 7,266 
model run short distance-based game against a student Physical education, health, and recreation program University of Lampung that consists of 19 items short run model. With the model running shorter distance learning can enhance the learning interest and prevent the boredom of students in learning due to the varied learning model so that the learning process is not running monotonous and boring.

\section{REFERENCES} pre-and post-test-a test that Ran the short distance Learning model for university students of Lampung developed effective and can increase the short-haul Run Student Learning Physical education, health, and recreation program University of Lampung.

The average value of a student Physical education, health, and recreation program University of Lampung before given a model of learning is 7,266 and value after being given the treatment Learning model Run short distances is 6,095 which means that there is an increase in the result of pre-test and posttest so the ability Run short distances Students Physical education, health, and recreation program University of Lampung on the rise. Based on these results it can be concluded that Running a short distance Learning model for university students of Lampung is effective and can increase the capability of Running shorter distance compared to a group that is not given the treatment Model Run a short distance learning for students of the University of Lampung that have been developed have significant effectiveness.

\section{CONCLUSION}

On the basis of the data obtained from the results of tests of the researchers of the field and the discussion of research results it can be concluded that: generating the final product in the form of a learning model run short distance-based game against a student Physical education, health, and recreation program University of Lampung that consists of 19 items short run model. With the model running shorter distance learning can enhance the learning interest and prevent the boredom of students in learning due to the varied learning model so that the learning process is not running monotonous and boring $[10,12$, 25]

- Conclusion on the basis of the data obtained from the results of tests of the researchers of the field and the discussion of research results it can be concluded that: generating the final product in the form of a learning model run short distance-based game against a student Physical education, health, and recreation program University of Lampung that consists of 19 items short run model. With the model running shorter distance learning can enhance the learning interest and prevent the boredom of students in learning due to the varied learning model so that the learning process is not running monotonous and boring

- Conclusion on the basis of the data obtained from the results of tests of the researchers of the field and the discussion of research results it can be concluded that: generating the final product in the form of a learning
[1] K.N. Anggelia, "Hubungan Aktivitas Fisik Dengan Indeks Massa Tubuh Siswa Late Adolescenes," J. Terap. Ilmu Keolahragaan, 2017.

[2] C. Gay, A. Chabaud, E. Guilley, and E. Coudeyre, "Educating patients about the benefits of physical activity and exercise for their hip and knee osteoarthritis. Systematic literature review," Annals of Physical and Rehabilitation Medicine. 2016.

[3] T. Slack, "From the Locker Room to the Board Room: Changing the Domain of Sport Management," J. Sport Manag., 2016.

[4] G. Glassman, "CrossFit Level 1 Training Guide," CrossFit J., 2010.

[5] T. Bompa and C. Buzzichelli, Periodization Training for Sports-3rd Edition. 1999.

[6] D.N. Boehm and T. Hogan, "Science-to-business collaborations: A science-to-business marketing perspective on scientific knowledge commercialization,” Ind. Mark. Manag., 2013.

[7] K. Green and K. Hardman, "Physical education: Essential issues," Phys. Educ. Essent. Issues, pp. 1-248, 2005.

[8] H.A. Riemer and P. Chelladurai, "Leadership and Satisfaction in Athletics,” J. Sport Exerc. Psychol., 2016.

[9] J. Stolk and J. Harari, "Student motivations as predictors of high-level cognitions in project-based classrooms," Act. Learn. High. Educ., 2014.

[10] M. Emzir, "Metodologi Penelitian Kualitatif Analisis data," Jakarta Raja Graf., 2012.

[11] R.M. LoPachin, T. Gavin, A. DeCaprio, and D.S. Barber, "Application of the Hard and Soft, Acids and Bases (HSAB) theory to toxicant Target interactions," Chemical Research in Toxicology. 2012.

[12] M.D. Gall, J.P. Gall, and W.R. Borg, "Educational Research (Seventh edition)," Educational Research: An introduction. 2003.

[13] A.M. Smith, "Research Methodology: A Step-by-step Guide for Beginners," Nurse Educ. Pract., 2011.

[14] P. Vickerman, "Teaching and learning strategies," in Teaching Physical Education to Children with Special Educational Needs and Disabilities, 2018.

[15] World Commission on Environment and Development, "Our Common Future - Report of the World Commission on Environment and Development (The Brundtland Report)," Med. Confl. Surviv., 1987.

[16] T.A. Beery, D. Shell, G. Gillespie, and E. Werdman, "The impact of learning space on teaching behaviors," Nurse Educ. Pract., 2013.

[17] S. Wills, "Strategic planning for blended eLearning," in 7th International Conference on Information Technology Based Higher Education and

[18] J. Jovanović, D. Gašević, S. Dawson, A. Pardo, and N. Mirriahi, "Learning analytics to unveil learning strategies in a flipped classroom," Internet High. Educ., 2017.

[19] Stroke-Association, "Stroke Statistic," Stroke Association Resource Sheet, 2016.

[20] S. Haji, "Pembelajaran tematik yang ideal di sd/mi," J. Progr. Stud. PGMI, 2015.

[21] D. Setia Ningrum and L. Leonard, "Pengembangan Desain Pembelajaran Matematika," Form. J. Ilm. Pendidik. MIPA, 2014.

[22] S. Sagala, "Pengertian Pembelajaran Menurut Para Ahli," Internet, 2009.

[23] J. Tangkudung, F. Dlis, and M.S. Saleh, "The Effect of Exercise and Kinesthetic Methods to Backhand Groundstroke Skills on Field Tennis Games,” JIPES - J. Indones. Phys. Educ. Sport, 2019. Training, ITHET, 2006. 
[24] W. Puspitorini, R. Kurniati, and J. Tangkudung, "Model Pembelajaran Berorientasi Fundamental Dengan Permainan Air Untuk Anak 5-6 tahun,” JPUD - J. Pendidik. Usia Dini, 2018.
[25] J. Tangkudung, Sport Medicine, Sport Psychometrics, vol. 1, no. 978602-425-590-9. 2018. 